application, and no injury to any of the plants was observed. Although no special apparatus is essential, the following method for distribution is suggested. A water suction pump (ejector) is attached to the garden tap, and hose piping leads from the suction opening into the barrel containing ammonium sulphide solution. The distributing hose is connected to the other end of the filter pump. On turning on the tap, the solution is drawn off from the barrel, mixed with water from the tap, and forced through the distributing hose. Calculation and trial are of course needed to determine the strength of ammonium sulphide solution in the barrel in order to yield 1 part in 30 in the distributing hose. Mr. Van Riper would welcome the reports of other experience in the use of this method for slug eradication.

\section{Narcissus Pests}

Bulletrin No. 51 of the Ministry of Agriculture and Fisheries (May 1932), entitled "Narcissus Pests", by Mr. W. E. H. Hodson, has recently come to hand. The object of this publication is to provide growers with reliable and up-to-date information enabling them to control the more common and destructive of the enemies of the narcissus. The Bulletin deals with the species of flies of which the larvæ are persistent enemies of the bulbs, while eelworms, mites, and other pests are also fully discussed. The most satisfactory treatment for all such pests is the submersion of the bulbs in water maintained at a temperature of $110^{\circ} \mathrm{F}$. for three hours. If such treatment were not available it is highly probable that the bulb eelworm would by now have rendered commercial growing almost impracticable. The Bulletin is obtainable, price 18. net, from H.M. Stationery Office or through any bookseller.

\section{Penguins' Eggs}

THE appearance of the eggs of penguins in some of the large London stores, where they were sold as epicurean novelties at ten shillings a dozen, led the Royal Society for the Protection of Birds to make inquiries regarding the source and supply (Bird Notes and News, vol. 15, No. 2, p. 39, 1932). The eggs were those of the Cape or black-footed penguin (Spheniscus demersus), and were obtained in one of the extensive penguin rookeries in the Cape Province of the Union of South Africa. The eggs were collected for sale under Government regulation, and the Trade Commissioner for South Africa informed the Society that during the months of April and May of the present year some 2000 dozen of the eggs were exported to Great Britain. We hope that the Government department which regulates the taking of the eggs will see to it that the strength of the penguin colony is not too seriously reduced, remembering the fate of the gare-fowl when commerce invaded its innumerable hordes ; and we trust that the exceptional opportunity will be taken of associating the statistics of eggs taken with the total strength of the colony year by year, for the study of the effect upon the population of the colony as a whole.

\section{Monument to Laplace}

THE issue of Revue Scientifique for Aug. 13 briefly records the inauguration on July 3 of a monument to the great French mathematician, Laplace, at his birthplace, Beaumont-en-Auge (Calvados). The monument, which is the work of M. R. Delandre, has been erected by international subscription, among the principal contributors to which were Messrs. J. H. Fry and J. Flanagan, of the United States, and the two Carnegie Foundations for Science and Peace. The unveiling took place in the presence of Maréchal Franchet d'Esperey, of the Société de Géographie of Paris, and distinguished representatives of the Academy of Sciences, the Paris Observatory, and the École Polytechnique. As recorded in NATURE for April 2, 1927, p. 493, at his death in March 1827 Laplace was buried in the Père Lachaise cemetery in Paris, but sixty-one years later, in 1888 , his remains were exhumed and reinterred in the grounds of the family estate at the little hamlet of Saint Julien de Mailloc, situated between Lisieux and Orbec (Calvados). At the time of the reinterment, the monument which had marked the resting-place of Laplace in Paris was presented to the commune of Beaumonten-Auge, and was re-erected in the cemetery there.

\section{Discovery of the Deviation of the Compass}

In the July issue of Science Progress, Mr. N. H. de V. Heathcote brings together the data at present available for fixing the date of the discovery of the deviation of the compass from true north. The figure in the instructions of the Nautical Chart of Bianco of 1436 which has been taken as evidence that a correction for a deviation of $18^{\circ}$ west of true north was allowed for, the author concludes has nothing to do with deviation. The first definite record of deviation he considers to be that made by Columbus in September 1492, during his first voyage across the Atlantic. In his record of his return in 1496 from his voyage to India, Columbus mentions Flemish compasses which read $111^{\circ}$ west of north when the Genoese compasses read north. Mr. Heathcote points out that pocket sundials were in use in Germany about the middle of the fifteenth century which were set in the meridian by a compass; in the latter an allowance for a deviation of $6^{\circ}$ east of true north was made, while in Etzlaub's road map of Germany of 1492 instructions are given for orienting it correctly by compass, an allowance for deviation of $11 \frac{1}{4}^{\circ}$ being made. He concludes that pocket sundials with an arrow set $111^{\circ}$ east of north were familiar objects in Germany before the time of Columbus.

\section{Bibliography of Line Spectra}

No better comment could be made on the present importance of line spectroscopy than the publication by the American Physical Society in Reviews of Modern Physics (April) of a bibliography of the papers which have appeared between 1920 and 1931. This has been compiled by R. C. Gibbs, and is prefaced by a short elementary account of the interpretation of spectra. The bibliography is divided into three sections. The first, which contains the majority of the references, is a list of those papers which contained new data or discussions; these are divided according to elements, stage of ionisation, year of publication, and alphabetical order of authors, and in general, when one paper has dealt with several elements, it

No. 3279, VoL. 130] 